\title{
一般口演 11
}

\section{咀嚼の意識化による咀嚼および嚥下の変調について}

\section{Changing mastication and swallowing by volitional chewing}

\author{
○阿志賀大和 ${ }^{1,2)}$, 鈴木 拓 $^{1)}$, 真柄 仁 $^{1)}$, 竹石龍右 ${ }^{1)}$, 辻村恭憲 ${ }^{1)}$, 井上 誠 $^{1)}$ \\ $\bigcirc$ Hirokazu Ashiga ${ }^{1,2)}$, Taku Suzuki ${ }^{1)}$, Jin Magara ${ }^{1)}$, Ryosuke Takeishi $^{1)}$, Takanori Tsujimura ${ }^{1)}$, Makoto Inoue ${ }^{1)}$ \\ 1) 新潟大学大学院医歯学総合研究科摂食舆下リハビリテーション学分野 \\ 2) 新潟リハビリテーション大学医療学部リハビリテーション学科言語聴覚学専攻 \\ ${ }^{1)}$ Dysphagia Rehabilitation, Niigata University Graduate School of Medical and Dental Sciences \\ ${ }^{2)}$ Department of Speech-Language-Hearing Therapy, Niigata University of Rehabilitation
}

\section{I. 目的}

咀嚼や嚥下などの摂食行動は, 日常意識することなく 実行可能である。一方, 摂食嚥下障害患者の食事指導に 際しては, 安全な経口摂取のためにこれらの運動を意識 させることが多い.しかし, 自然咀嚼と指示咀嚼では, 口腔内での食塊の流れが異なることから ${ }^{11}$, 意識下での 咀嚼嚥下運動は関連する筋活動や食塊物性などが異なる 可能性があり，その違いを理解することは重要である.

本研究では, 健常者を対象として生理学的な手法を用 いて, 咀嚼を意識した際に生じる咀嚼や嚥下運動の変化 を調べた。

\section{II. 方 法}

\section{1. 対象}

摂食嚥下機能に臨床的問題のない健常成人 15 名（女 性 7 名, 男性 8 名, 年齢 $25.7 \pm 5.4$ 歳）を対象とした. 被験者は, 背もたれのある椅子に座り, 頸部を固定せず, フランクフルト平面が床と水平になるように調整した。

\section{2. 試験食品}

米飯 $8 \mathrm{~g}$ (こしひかりごはん, テーブルマーク株式会 社）を用いた。

\section{3. 測定項目}

左右咬筋，ならびに舌骨上筋群表面筋電図，嚥下内視 鏡画像を記録した。

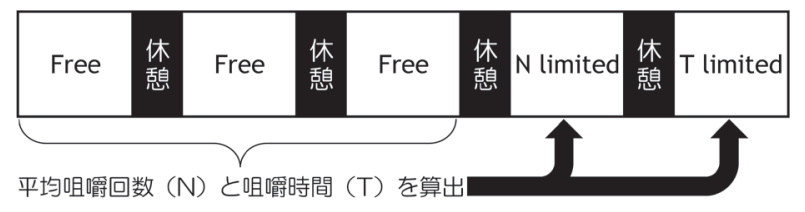

図 1 実験プロトコール

\section{4. 実験プロトコール}

最初に, 自由咀嚼嚥下（Free）を 3 回記録した。被 験者ごとに, 咀嚼開始から 1 回目の嚥下までの咀嚼回 数, 咀嚼時間, 咀嚼サイクル時間の平均值を求めた。 こ れらの值を用いて, 指定した回数を咀嚼してから嚥下す る回数限定咀嚼嚥下 (N limited), 験者が時間を測定し た後に嚥下をしてもらう時間限定咀嚼嬹下（T limited） を記録した（図 1 ）。

\section{5. 解析}

1) 咀嚼運動比較

咀嚼時間, 咀嚼回数, 咀嚼サイクル時間の平均值を求 めて, タスク間で比較した。

2) 時間経過に伴う筋活動の変化

咀嚼時間を時間で等分して前期 (Early), 中期 (Middle), 後期（Late）に分け, 各期の 1 咀嚼サイクル あたりの筋活動量を求めて時間経過に伴う筋活動量の変 化を調べた，また，前期の 1 咀嚼サイクルあたりの筋活 動量を 1 として, 時間経過に伴う筋活動の変化をタスク 間で比較した。 
3）咀嚼中の食塊の咽頭移送

自然咀嚼中には, 嚥下前の食塊の咽頭移送（Stage II 移送，StII）が頻回に観察される。内視鏡画像から観察 された StII 被験者数, StII 頻度, StII 時間の違いを夕 スク間で比較した。

4）嚥下活動

嚥下時の舌骨上筋群筋活動量をタスク間で比較した。

\section{III. 結果及び考察}

1. 咀嚼時間, 咀嚼回数, 咀嚼サイクル時間のタスク間 比較（図 2)

咀嚼時間；条件間で有意差はみられなかった。咀嚼回 数; T limitedに打いて有意に咀嚼回数が増加した。咀 嚼サイクル時間； T limitedに扔いて有意に短かった。 タスクの違いは, 咀嚼運動様式に若干の変化を与えた。

\section{1 咀嚼サイクルあたりの筋活動量の変化}

咬筋および舌骨上筋群活動量ともに, 時間経過に従い 有意に減少した（図 3，4）。減少量は, 舌骨上筋群筋活 動量に㧍いて, Free と T limitedの間に差が認められ, 後者では筋活動の減少が有意に大きかった（図５）。咀 嚼の意識化が咀嚼中の筋活動様式にも変化を与えること が示唆された。

\section{St Пの頻度および St I時間}

StII はFree で頻度が高かった. StII 時間はFree で 有意に長かった（図 6 )。咀嚼を意識させることにより， 咀嚼中の食物の口腔内保持を優先させていた。このこと が, 咀嚼運動や筋活動様式の違いを生んだ可能性があ る.

\section{4. 嚥下時筋活動}

燕下時の舌骨上筋群の活動量には条件間に差が認めら れなかったが, Free 時の值が小さくなる傾向を示した. 咀嚼の意識化は, 咀嚼時の食塊形成やそれに続く嚥下に も影響を与えることが示唆された。

\section{N. 文 献}

1) Palmer, JB et al: Volitional Control of Food Transport and Bolus Formation during Feeding. Physiol Behav. 2007; 91(1): 66-70.
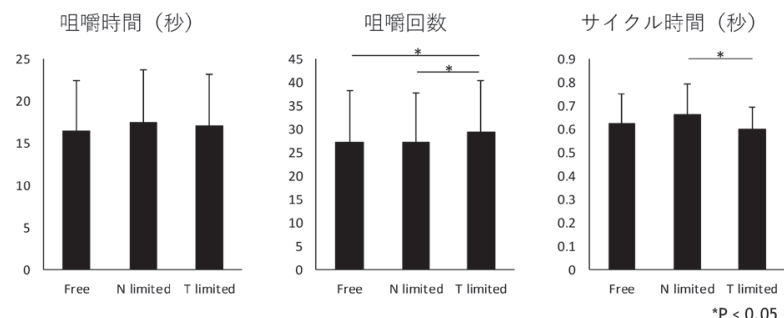

図 2 咀嚼時間, 咀嚼回数, 咀嚼サイクル時間
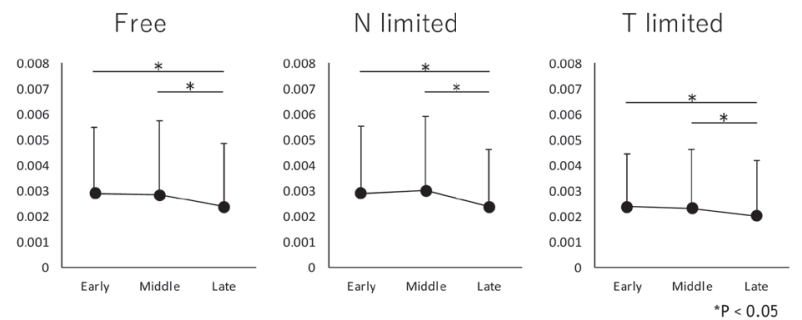

図 3 咬筋の咀嚼サイクル活動量 $(\mathrm{Vs} \cdot \mathrm{s}$ )
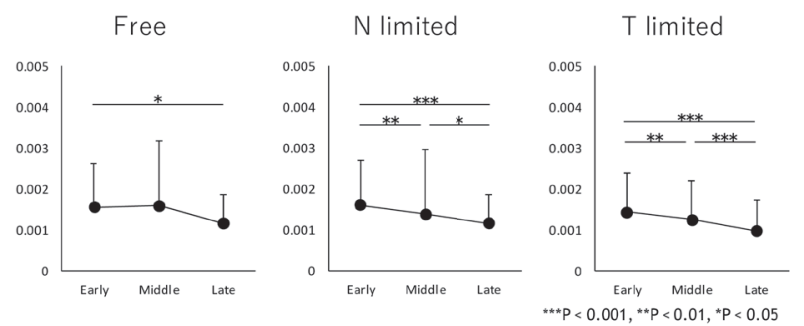

図 4 舌骨上筋群の咀嚼サイクル活動量 $(\mathrm{Vs} \cdot \mathrm{s})$

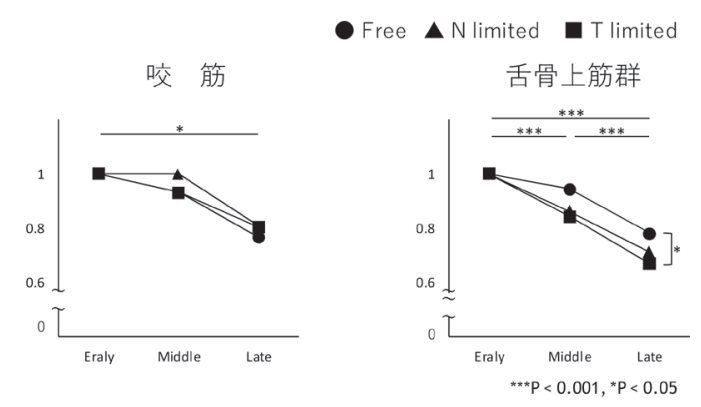

図 5 筋活動量の経時的変化の夕スク間比較

被験者数

StII頻度（\%)

StII時間（秒）
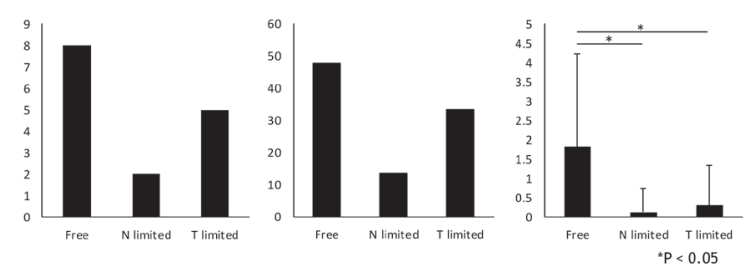

図 6 StII のタスク間比較 